\title{
HISTÓRIA, MEMÓRIA E ESQUECIMENTO NO CINEMA BRASILEIRO: A CONTRIBUIÇÃO DA ORGANIZAÇÃ O DA INFORMAÇÃO NA RECOSNTRUÇÃO DA IMAGEM SOCIAL DO PERSONAGEM HOMOSSEXUAL
}

\author{
Fabio Assis Pinho \\ Doutor em Ciência da Informação pela UNESP \\ Programa de Pós-Graduação em Ciência da Informação - UFPE \\ fabiopinho@ufpe.br \\ Francisco Arrais Nascimento \\ Mestre em Ciência da Informação pela UFPE \\ Programa de Pós-Graduação em Ciência da Informação - UFPE \\ francisco.arrais.nascimento@gmail.com
}

\begin{abstract}
Resumo
O presente estudo foi desenvolvido a partir de uma perspectiva imagético discursiva, de reconstrução memorial da representação social do personagem homossexual no cinema brasileiro. Objetivamos compreender como a Organização da Informação (OI) auxilia, por meio da reconstrução da memória cinematográfica, na identificação temática relacionada à imagem social dos personagens homossexuais no cinema brasileiro. Utilizou-se de uma cartografia de telas com recorte cronológico compreendido entre os anos de 1980 a 2014 . O recorte analisado explicita que a utilização de um modelo preponderante com características, padrões, constitui um estereótipo, consolidando e arraigado em uma visão que representa o preconceito social e um proselitismo da sociedade com relação às homossexualidades.
\end{abstract}

Palavras-chave: Memória. Artefatos culturais. Cinema. Análise fílmica. Organização da informação.

\section{HISTORY, MEMORY, AND FORGETTING IN BRAZILIAN CINEMA: THE INFORMATION ORGANIZATION CONTRIBUTION TO THE RECONSTRUTION OF THE SOCIAL IMAGE OF HOMOSEXUAL CHARACTER}

\begin{abstract}
This study was developed from a discursive perspective imagery, memorial reconstruction of the social representation of the homosexual character in Brazilian cinema. We aim to understand how the Information Organization (OI) helps, by reconstructing the film memory, the theme identification related to social image of gay characters in Brazilian cinema. It used a mapping screens with chronological cut between the years 1980 to 2014. The analysis clipping explains that the use of a key model characteristics, patterns, is a stereotype, consolidating and rooted in a vision that is prejudice social and societal proselytizing regarding homosexualities.
\end{abstract}

Key-words: Memory. Cultural artifacts. Cinema. Filmic analysis. Information organization.

\section{Introdução}

Maurice Halbwachs ${ }^{1}$ (1877-1945) fora o primeiro sociólogo a fazer emergir a temática da memória sob a óptica das interações sociais, estabelecendo a tese de que os homens constroem

\footnotetext{
${ }^{1}$ Maurice Halbwachs estabeleceu os principais argumentos teóricos de defesa do caráter coletivo da memória coletiva em duas obras: "Les cadres sociaux de la mémoire" [Os quadros sociais da memória] (1925) e "A memória coletiva”, esta última publicada após sua morte (1950).
} 
suas memórias em um fluxo contínuo, a partir das interações sociais que os mesmos mantêm. Segundo Gondar e Dodebei (2005, p. 8), Halbwachs estabeleceu a memória como campo do conhecimento, antes de outros pesquisadores, como Friedrich Wilhelm Nietzsche (1844-1900), Henri Bergson (1859-1941) e Sigmund Schlomo Freud (1856-1939).

O posicionamento adotado por Halbwachs diverge da teoria vigente no período, promovendo uma ruptura no pensamento da época, que afirmava que a memória seria o resultado da impressão de eventos reais na mente humana. Tal ruptura proposta revela que a memória individual não pode ser distanciada das memórias coletivas, uma vez que, a memória individual traz em sua constituição a complexidade das interações sociais experienciadas pelo sujeito, enquanto a memória coletiva se apoia na memória individual influenciando sua produção de forma a estabelecer uma relação simbiótica.

Para Halbwachs (2006), a memória coletiva só é acionada quando as memórias individuais constituírem as linhas indispensáveis das lembranças e imagens remotas. Dessa forma Kessel (2004, p. 3 e 5) elabora a seguinte teoria:

As memórias individuais alimentam-se da memória coletiva e histórica e incluem elementos mais amplos do que a memória construída pelo indivíduo e seu grupo. Um dos elementos mais importantes, que afirmam o caráter social da memória, é a linguagem. As trocas entre os membros de um grupo se fazem por meio de linguagem. Lembrar e narrar se constituem da linguagem. Como afirma Eclea Bosi a linguagem é instrumento socializador da memória, pois reduz, unifica e aproxima no mesmo espaço histórico e cultural vivencias tão diversas como o sonho, as lembranças e as experiências recentes, [...] Já a memória histórica tem no registro escrito um meio fundamental de preservação e comunicação. Memória individual, coletiva e histórica se interpenetram e se contaminam. Memórias individuais e coletivas vivem num permanente embate pela coexistência e também pelo status de se constituírem como memória histórica.

Para tal estudo se faz necessário compreender os limites conceituais do que se propõe analisar, a saber, história, memória, esquecimento e as relações estabelecidas com os artefatos cinematográficos (cinema) no contexto das representações ${ }^{2}$ das homossexualidades nos últimos trinta e quatro anos.

Segundo Nora (1993, p 12):

Memória, história: não são sinônimos de modo algum; na verdade, como já sabemos hoje, são opostos em todos os aspectos. [...] A memória é sempre um fenômeno atual, uma construção vivida em um presente eterno, enquanto que a história é representação do passado. [...] A memória orienta a recordação para o

\footnotetext{
${ }^{2} \mathrm{Na}$ pesquisa em questão foram adotadas as linhas de Roger Chartier (1990) para designar as representações, quando o mesmo afirma que ela articula o mundo social com as "práticas que visam a fazer reconhecer uma identidade social, exibir uma maneira própria de estar no mundo, significar simbolicamente um estatuto e uma posição" (CHARTIER, 1990, p. 23).
} 
sagrado, a história expulsa-a: seu objetivo é a desmistificação. A memória surge a partir de um grupo cuja conexão ela estimula. [...] A história, por sua vez, pertence a todos e a ninguém, e por isso é designada como universal.

O construto conceituado na obra de Michel Pollak (1948-1992) é esclarecedor quanto as relações estabelecidas entre a ideia de uma identidade homossexual, a noção de silenciamento das memórias marginalizadas e a descrição de objetos nas áreas de Ciências Sociais e Humanas.

Compreendemos assim o esquecimento como componente fundamental na relação estabelecida entre história e memória. Conceitualmente compreendemos o esquecimento como a cessação da memória que se tinha. Trata-se de uma ação involuntária que supõe deixar de conservar na memória alguma informação que tinha sido adquirida. $\mathrm{O}$ mesmo pode ser influenciado pela ação do "Poder" que norteia por meio dos dispositivos de controle social o silenciamento dos discursos e dos construtos memoriais segundo o proselitismo eleito pelo mesmo. Logo, tal delineamento estrutural nos faz compreender que, o que fora construído no decorrer da história acerca das homossexualidades revela um discurso atroz que se manifesta em uma relação de poder compreendida sobre a óptica de Michel Foucault (1926-1984), em que a mesma se alastrara pelos mais diversos meios de coerção social descritos no conceito de dispositivo ${ }^{3}$.

Logo, compreendemos que dentre os vários elementos que emergem de uma análise social, a sexualidade tem papel privilegiado. Dessa forma, a temática sob uma perspectiva ampliada assume sua pluralidade aqui mencionada como sexualidades, neste caso sob o recorte das homossexualidades, em uma tentativa de contemplar a multiplicidade de tais experiências.

Assim, ao encararmos as homossexualidades como coisa, comportamento, fenômeno e acima de tudo um domínio a ser estudado e compreendido dada a sua importância, lançando sobre as mesmas o olhar cientifico humanizado e não o infectado pelo discurso médico cientifico que vigorara até as últimas décadas do século XX e que nos últimos anos vem ruindo frente a desconstrução dos estereótipos que figuraram os espaços de marginalização, patologização e exclusão além da consolidação da temática no âmbito das pesquisas de natureza social. Durval Muniz Albuquerque Júnior (2009, p.30) discorre que:

O discurso da estereotipia é um discurso assertivo, repetitivo, é uma fala arrogante, uma linguagem que leva à estabilidade acrítica, é fruto de uma voz segura e autossuficiente que se arroga o direito de dizer o que é outro em poucas palavras. O estereótipo nasce de uma caracterização grosseira e indiscriminada

\footnotetext{
${ }^{3}$ Cf Foucault (2000). A saber: [...] um conjunto decididamente heterogêneo que engloba discursos, instituições, organizações arquitetônicas, decisões regulamentares, leis, medidas administrativas, enunciados científicos, proposições filosóficas, morais, filantrópicas. Em suma, o dito e o não dito são os elementos do dispositivo. O dispositivo é a rede que se pode tecer entre estes elementos (Foucault, 2000, p. 244).
} 
do grupo estranho, em que as multiplicidades e as diferenças individuais são apagadas, em nome de semelhanças superficiais do grupo.

Assim podemos observar que temática apesar de auferir largo espaço na produção de informações dada a extensa produção de conteúdo para os diversos meios de comunicação e todo o aparato tecnológico, ainda apresenta uma forte perspectiva patologizante que permeia as relações, ancorada na visão biomédica que alicerça os discursos desde o século XIX.

A sexualidade é representada através dos artefatos culturais, estes frutos das produções midiáticas, tanto de natureza jornalística quanto ficcional. Sendo percebida a partir da emergência de identidades que ocupam papéis e ressaltam aspectos sexuais, sendo enquadrados dentro do desvio, fora da norma hegemônica da heterossexualidade. Segundo Butler (2006, p. 69):

Uma norma não é o mesmo que uma regra e tampouco é o mesmo que uma lei. Uma norma opera dentro das práticas sociais como o estandarte implícito da normalização. [...] As normas podem ser explícitas, sem dúvida, quando funcionam como o princípio normalizador da prática social, mas em geral permanecem implícitas, são difíceis de ler, os efeitos que produzem são a forma mais clara e dramática mediante a qual se podem discernir.

Assim, segundo Woodward (2000, p. 8) "As identidades adquirem sentido por meio da linguagem e dos sistemas simbólicos pelos quais elas são representadas [...] Existe uma associação entre a identidade da pessoa e as coisas que ela usa". Desta maneira, o cinema como artefato cultural, expressa sua visão para aqueles que assistem às suas produções, Rossini (2004, p.2):

[...] enquanto produtor de discursos que ajudam a dar visibilidade às representações sociais em torno das identidades culturais, nos permite compreender tanto os enfrentamentos, quanto às permanências e as mudanças presentes no campo social. Sendo o cinema um meio que articula discursos verbais e imagéticos [...].

Dessa forma podemos compreender que lésbicas, gays, travestis, transexuais, intersexuais, crossdressers $(C D)^{4}$, drag queens, drag kings ${ }^{5}$, homens que fazem sexo com

\footnotetext{
${ }^{4}$ Cross-dressing é o termo que se refere a pessoas que vestem roupa ou usam objetos associados ao sexo oposto, por qualquer uma de muitas razões, desde vivenciar uma faceta feminina (para os homens), masculina (para as mulheres), motivos profissionais, para obter gratificação sexual, ou outras. O crossdressing, não está relacionado com a orientação sexual, e um crossdresser pode ser heterossexual, homossexual, bissexual ou assexual. O crossdressing também não está relacionado com a transexualidade.

${ }^{5}$ Drag queens ou Drag kings são artistas performáticos que se travestem, fantasiando-se cômica ou exageradamente com o intuito geralmente profissional artístico. Chama-se drag queen o homem que se veste com roupas exageradas femininas estilizadas, e drag king a mulher que se veste como homem. $\mathrm{O}$ artista transformista passou a ser chamado de drag queen há pouco tempo. "Dr. A.G." (Dressed As a Girl, traduzido por "vestido como uma garota") foi uma sigla utilizada por William Shakespeare para diferencias seus atores no roteiro das peças.
} 
homens (HSH), gOys $s^{6}$ entre outras manifestações identitário/sexuais suscitam a cena e em destaque provocam discussões voltadas para uma perspectiva aberta ao repensar das posições dos sujeitos no contexto social. Embora o conceito aplicado socialmente de desviante, perverso, nefandun ${ }^{7}$, abjeto, invertido e sodomita tenha se deslocado durante a construção histórica e cultural no Brasil, ainda assim se pode observar que as homossexualidades têm ocupado local de destaque dentre tais conceituações no decorrer da história e da evolução do conhecimento cientifico.

Pode-se ainda ressaltar que apesar de os padrões estéticos, morais, científicos, políticos e culturais tenham evoluído durante a história ainda assim a condição de errante, desviante e contrária a norma ainda permanece arraigado sobre os praticantes de modalidades alternativas de sexualidade.

Assim, sob a óptica da ciência da informação (CI) a identificação de assuntos (necessária no processo de compreensão e análise em estudos na área), ocorrida na etapa analítica de um documento submetido ao tratamento temático, constitui um campo de estudo carente de metodologias que auxiliem o leitor na seleção de conceitos que propiciem os subsídios necessários à elaboração dos produtos documentários decorrentes desse processo. Conceitos

esses que apesar de terem evoluído no decorrer da história ainda se encontram em construção uma vez que se tratando da sexualidade humana uma possível taxonomia se torna complexa dada as múltiplas formas de manifestação da mesma, mesmo no contexto da homossexualidade.

No âmbito da Ciência da Informação (CI), Otlet (1937) ${ }^{8}$ documento pode ser definido como:

Documento é o livro, a revista, o jornal, é a peça de arquivo, a estampa, a fotografia, a medalha, a música, é também atualmente o filme, o disco e toda a parte documental que prece ou sucede a emissão radiofônica. Ao lado dos textos e imagens há objetos documentais por si mesmos.

Sabe-se que no século XIX, segundo afirma Paul-Michel Foucault (1926-1984) em sua obra: História da sexualidade I: a vontade de saber (1988) com o advento do capitalismo e o nascimento das ciências humanas buscou cada vez mais explicações no campo da sexualidade, onde a mesma passa a se constituir cada vez mais como central na constituição do sujeito

\footnotetext{
${ }^{6} \mathrm{O}$ termo " $g 0 y$ " ou " $g-y$ " é abrangente, podendo incorporar comportamentos diversos como atitude, postura masculina, pró-atividade, entre outros, mas o principal é que com o zero em destaque no termo $g 0 y$ serve para designar homens que não praticam sexo anal com outros homens.

${ }^{7}$ Ver comunicação apresentada no "Seminário-Taller de História de las Mentalidades y los Imaginarios", realizado na Pontíficia Universidad Javerina de Bogotá, Colômbia, Departamento de História e Geografia, 22-26/8/1994. Apresentado pelo livre docente Luiz Roberto de Barros Mott.

${ }^{8} \mathrm{O}$ texto do qual tal citação fora extraído não apresenta paginação, no entanto está disponível em formato digital sob a seguinte descrição e sítio: OTLET, Paul. Documentos e documentação. Disponível em:

<http://www.conexaorio.com/biti/otlet/>. Acesso em: 03 ago. 2015.
} 
moderno, em um processo de valorização da intimidade que já encontrava-se em processo de abertura desde o Romantismo, produzindo assim múltiplos discursos sobre as práticas sexuais.

Tem-se claro que o discurso é um mecanismo utilizado por meio da sociedade para normatizar, vigiar e punir o corpos abjetos em uma perspectiva de disciplinarização dos corpos. Nesse aspecto a sexualidade apresenta-se como um "dispositivo histórico". Uma vez que a sexualidade é um construto histórico-social, a mesma está submetida a múltiplos discursos sobre a manifestação e regulação da própria. Discursos esses que normatizam, instauram prazeres e produzem “verdades". Assim, segundo Canevacci (1990, p.135):

Partindo da tese de que houve uma precisa era histórica, caracterizada pela articulação entre visões do mundo cristãs-patriarcais e produção de mercadorias, que legitimaria os comportamentos "femininos" de passividade como se fossem próprios apenas da mulher (e, enquanto tais, julgados negativamente), o cinema atua seja com base bissexual, seja com base na ideologia patriarcal dos espectadores. O resultado é que esses últimos - não importa a que sexo pertençam - são feminizados na acepção crista-burguesa do termo, o que significa que são artificialmente solicitadas as latências homossexuais tanto do homem como da mulher, fazendo-lhes sofrer com angustias e terror a perda da própria identidade sexual.

Segundo Moreno (1995) o artefato cultural de natureza cinematográfica tem por objetivo

transmitir uma mensagem através de uma composição de som e imagem, obedecendo a códigos que são estabelecidos pela técnica cinematográfica e tem origem nas demandas sociais.

Portanto, através de uma produção cinematográfica, os personagens homossexuais são submetidos ao processo de observação, análise e classificação, onde cabe ao receptor observador atribuir as características referentes a função de tal sujeito na sociedade em que o mesmo está inserido. O processo de julgamento e avaliação são invariavelmente arraigados nos padrões estabelecidos pela própria sociedade, que no caso da pesquisa em questão tais raízes sociais são originadas em uma binaridade de gênero, que nesse caso coloca a homossexual como o sujeito da transgressão ou o sujeito dentro das ações limítrofes de desempenho que a sociedade impõe e espera dentro de sua dinâmica. Toda essa dinâmica pode ser explicada pela heteronormatividade ${ }^{9}$ compulsória imposta pela sociedade, que coloca a heterossexualidade no centro da norma como modelo a ser seguido e torna periféricas as manifestações alternativas de sexualidade.

Compreendemos que o cinema se constitui como um artefato cultural que representa e é representado como fator constituinte da sociedade em que o mesmo está imerso. Woodward (2000, p. 55) ressalta que:

\footnotetext{
${ }^{9} \mathrm{O}$ termo especifica a tendência, no sistema ocidental contemporâneo referente ao sexo-gênero, de considerar as relações heterossexuais como a norma, e todas as outras formas de conduta social como desviações dessa norma (SPARGO, 2004, p. 86).
} 
[...] quaisquer que sejam os conjuntos de significados construídos pelos discursos, eles só podem ser eficazes se eles nos recrutam como sujeitos. Os sujeitos são, assim, sujeitados ao discurso e devem, eles próprios, assumi-lo como indivíduos que, dessa forma, se posicionam a si próprios. As posições que assumimos e com as quais nos identificamos constituem nossas identidades.

Dessa forma na composição dos personagens homossexuais, são alocados recursos socioculturais, nos quais o cinema se insere de maneira contundente, fazendo emergir problemáticas e conferindo-lhes posição privilegiada no âmbito do debate social ou, simplesmente, alocando-a como uma questão desviante, marginal e periférica sob a óptica da norma vigente. No segundo caso, estará reforçando preconceitos e consolidando estereótipos, fato esse que impede a evolução da temática sob o aspecto de sua representação frente ao construto deturpado da imagem das homossexualidades na sociedade, contexto esse que serve como cenário da análise aqui apresentada.

Logo segundo Halbwachs (2006) as identidades dos grupos humanos e dos indivíduos são construções históricas baseadas na memória. Em vários momentos, Maurice Halbwachs (2006, p.12) insinua não apenas a seletividade de toda memória, mas também um processo de "negociação" para conciliar memória coletiva e memórias individuais: "Para que nossa memória se beneficie da dos outros, não basta que eles nos tragam seus testemunhos: é preciso também que ela não tenha deixado de concordar com suas memórias e que haja suficientes pontos de contato entre ela e as outras para que a lembrança que os outros nos trazem possa ser reconstruída sobre uma base comum."

Podemos assim compreender como os dispositivos de controle e coerção social atuaram historicamente controlando "o que lembrar", "como lembrar" e principalmente "o que deve ser preservado e representado".

Segundo Pollak (1989, p. 6) o Estado e seus mecanismos de controle por meio dos dispositivos vigiam, coíbem e tentam controlar as memórias tornando subterrâneas todas as representações e resquícios memoriais que desviem da norma vigente, tal fenômeno se mantem até que seja propicio que esse material memorial emerja no contexto social, logo:

[...] Ele (o fenômeno) consiste muito mais na irrupção de ressentimentos acumulados no tempo e de uma memória da dominação e de sofrimentos que jamais puderam se exprimir publicamente. Essa memória "proibida" e portanto "clandestina" ocupa toda a cena cultural, o setor editorial, os meios de comunicação, o cinema e a pintura, comprovando, caso seja necessário, o fosso que separa de fato a sociedade civil e a ideologia oficial de um partido e de um Estado que pretende a dominação hegemônica. Uma vez rompido o tabu, uma vez que as memórias subterrâneas conseguem invadir o espaço público, reivindicações múltiplas e dificilmente previsíveis se acoplam a essa disputa da memória, no caso, as reivindicações das diferentes nacionalidades. 
Dessa forma se pode vislumbrar a importância do artefato cultural cinematográfico no âmbito social e por meio das informações obtidas através de análise fílmica elaborar um texto conclusivo que tentará explicitar o discurso que o cinema brasileiro apresenta sobre as homossexualidades enfatizando duas vertentes. A primeira compreende a larga produção de artefatos fílmicos que reproduzem um modelo preponderante de personagem que age sob a forma de estereótipo na desconstrução de um discurso positivo sobre as homossexualidades e a segunda que observa como de forma mais restrita a produção fílmica procura avançar em um questionamento sobre a temática, mais próximo da realidade. Confluência essa que resulta em uma cartografia que evidencia como a Organização da Informação (OI) auxilia na identificação temática relacionada à imagem social dos personagens homossexuais no cinema brasileiro.

Assim, ao imergirmos no universo dos artefatos culturais sob óptica memorial orientados sob influência da Ciência da Informação e consequentemente da Organização do Conhecimento, mais precisamente a produção cinematográfica que atua em tempos hodiernos como agente de tutela memorial e de representação social, podemos vislumbrar as indagações que emergem e norteiam tal pesquisa. Como o cinema brasileiro apresenta a temática homoafetiva e/ou personagens homossexuais representados e como a Organização da Informação (OI) auxilia na reconstrução das memórias subterrâneas que envolvem os personagens homossexuais?

Logo objetivamos com tal estudo compreender como a Organização da Informação (OI) auxilia, por meio da reconstrução da memória cinematográfica, na identificação temática relacionada à imagem social dos personagens homossexuais no cinema brasileiro.

\section{Aspectos metodológicos}

Metodologicamente este estudo centra-se em uma perspectiva qualitativa, de cunho exploratório, tomando enquanto objeto de estudo os artefatos audiovisuais que apresentam em seu contexto fílmico personagens homossexuais.

A coleta de dados seguiu o seguinte roteiro:

1 Identificação de base de dados a ser utilizada, que nesta pesquisa adotou-se a base da dados da cinemateca nacional, inscrita sob o endereço: www.cinemateca.gov.br;

2 Definição de descritor de busca, sendo eles: Homossexual, Homossexualidade e Cinema;

3 Identificação de um universo no acervo digital, onde o mesmo apresenta a extensão de 105 produções cinematográficas de (1920-2014), selecionadas segundo a disponibilidade, relevância e alinhamento com os objetivos da pesquisa. 
Elegeu-se com base no objetivo da pesquisa a metodologia proposta por Moreno (1995) que apresenta por método de análise fílmica uma cartografia que possibilita a construção de um painel da produção fílmica, que na pesquisa em questão será das últimos trinta e quatro anos informando o tratamento dado na composição dos personagens homossexuais. Assim fora realizada uma abordagem didática dos 186 filmes identificados e analisados que apresentam em seu enredo personagens de natureza homossexual.

Analisar um filme, segundo Leutrat (1995, p. 32), é:

[...] delimitar um terreno, medi-lo, esquadrinhá-lo muito precisamente (trata-se de um fragmento de obra ou de uma obra inteira). Uma vez recortado e batizado o terreno, devemos nele, e em conformidade com a sua natureza, efetuar seus próprios movimentos de pensamento. Para este périplo é imperativo dispor de várias cartas, ou seja, de instrumentos trazidos de disciplinas diversas, para que se possa superpô-las, saltar de uma a outra, estabelecer as passagens, as trocas e as transposições [...]. A descoberta de tais signos depende das questões postas às obras, cada obra necessitando de questões particulares. Como diz Gérard Granel, "não há migalhas numa obra, nem 'triagem' possível entre o que seria importante, revelador ou insignificante". [...] Afinal de contas, tudo pode ser levado em conta, dado que é disto que o sentido advém.

Logo surge uma indagação: Como analisar de forma satisfatória uma quantidade tão

grande de artefatos cinematográficos? O ponto inicial da pesquisa fora verificar a existência de outras experiências de pesquisa exitosas em sua trajetória. Logo, a pesquisa realizada por

Moreno (2001), que analisou a representação de homossexuais no cinema brasileiro através de um método com base na semiótica. Moreno, até 1996, já havia computado 125 produções com personagens homossexuais.

Moreno adapta e divide seu modelo analítico simplificado em dois níveis: o de estrutura (que identifica o nível sintático) e o de significação (que analisa os níveis semântico e pragmático). A ferramenta de identificação desse último nível é o gestual empregado pela personagem homossexual. Ele estabelece ainda um vetor resultante das análises denotativa e conotativa de cada filme estudado, que classifica de pejorativo, não pejorativo ou dúbio (PERET, 2005, p. 114).

Quadro- Estrutura do modelo de análise. Modelo de análise fílmica estrutural/significativa

\begin{tabular}{c|c|c|c}
\hline \multirow{4}{*}{01} & \multicolumn{3}{|c}{ Análise Estrutural ou Sintática } \\
\cline { 2 - 4 } 0 & Titulo & \multicolumn{3}{|c}{} \\
\cline { 2 - 4 } & Gênero & Ano & \\
\cline { 2 - 4 } & $\begin{array}{c}\text { Elenco e } \\
\text { Personagens }\end{array}$ & \\
\cline { 2 - 4 } & Sinopse & \multicolumn{2}{|c}{} \\
\hline \multirow{2}{*}{02} & \multicolumn{2}{|c}{ Analise Significativa (Significante e Significado) } \\
\end{tabular}




\begin{tabular}{|c|c|c|c|c|}
\hline & & \multicolumn{2}{|c|}{ Significante (Denotação) ${ }^{10}$} & Significado (Conotação) $)^{11}$ \\
\hline & \multirow{6}{*}{$\begin{array}{l}\text { Linguagem } \\
\text { narrativa }\end{array}$} & Posição da região no enredo fílmico & & Analise da Hist6ria do Filme \\
\hline & & Contexto social & & \\
\hline & & Recursos Narrativos & & \\
\hline & & Tipo de montagem & & \\
\hline & & Tipo de Interpretação & & \\
\hline & & Analise da Hist6ria do filme & & \\
\hline & \multirow{3}{*}{$\begin{array}{l}\text { Linguagem } \\
\text { Gestual }\end{array}$} & \multirow{3}{*}{ Tipo de Gestualidade ${ }^{12}$} & Estereotipada & Características \\
\hline & & & Não-estereotipada & Pejorativa \\
\hline & & & Inexistente & Não-pejorativa \\
\hline \multirow[b]{2}{*}{03} & \multicolumn{4}{|c|}{ Retrato Fílmico Encontrado } \\
\hline & \multicolumn{4}{|c|}{$\begin{array}{l}\text { Texto conclusivo sobre o teor do discurso apontado no filme sobre o assunto, podendo ser: } \\
\text { Pejorativo, não-pejorativo e dúbio. Será assim descrito }\end{array}$} \\
\hline
\end{tabular}

Fonte: Adaptado de Moreno (1995)

As cronologias apresentadas como fruto da cartografia foram compostas a partir de sinopses, fichas técnicas e dos próprios filmes. Como alicerce para o estudo se fez uso da base de dados do Ministério da Cultura intitulada na Cinemateca brasileira, permitindo movimentos que possibilitaram contato com a experiência cinematográfica dos autores. Assim, a pesquisa aqui apresentada fez uso de cartografia para a reconstrução da memória do cenário fílmico com personagens homossexuais produzidos no Brasil no período de 1920 a 2014, onde o universo levantado compreende 186 obras cinematográficas distribuídas segundo o Gráfico 1, no entanto é importante ressaltar que não se trabalhou nessa pesquisa com o universo levantado dado a inviabilidade e inexistência de acervo fílmico com tais obras, sendo necessário para a viabilização de tal análise a realização do recorte cronológico (1980-2014) da produção cinematográfica do país.

Buscou-se representar o cenário nacional de produção cinematográfica por meio do levantamento cartográfico das produções com temática e/ou personagens homoafetivos sob as mais diversas vertentes de representação das homossexualidades.

A análise proposta foi realizada em dois níveis: o da estrutura e o da significação. O nível da estrutura compreende os dados que descrevem a produção cinematográfica e tem natureza fixa, tais como: Título, gênero, cor, duração, elenco, personagens e sinopse.

O nível da significação é construído sob dois pontos de observação, sendo eles o da linguagem narrativa e o da linguagem estético/gestual que nos permitirá visualizar o teor do discurso sobre a homossexualidade. A linguagem narrativa compreende os aspectos discursivos

\footnotetext{
${ }^{10}$ Comentários sobre como o filme conduz o personagem dentro de seu enredo fílmico.

${ }^{11}$ Comentários sobre o que o enredo do filme induz o observador a julgar em relação ao religião abordada no enredo fílmico.

${ }^{12}$ Comentário descritivo da gestualidade e sub gestualidade empregada no filme.
} 
que compõe a narrativa e constitui a própria história e a posição ocupada pelos personagens homossexuais dentro de tal enredo. Já a linguagem estética/gestual compreende a gestualidade e sub gestualidade empregada na composição e caracterização do personagem analisado além do figurino, cenário e discursos em que o mesmo está imerso.

Conforme Pinto-Molina, em sua obra Análisis documental: fundamentos $y$ procedimentos, publicada no ano de 1993, o tratamento temático da informação (TTI) é considerada a área que se encarrega da identificação de assuntos e conceitos presentes em um documento e como estes podem vir a ser representados. Em consonância com tal pensamento Guedes (2009) aponta que o TTI, é o processo responsável em gerar subprodutos de um documento a partir das suas representações temáticas, que serão utilizados também como instrumentos de busca. Logo segundo relembra Foskett (1973, p.3) em sua obra:

[...] a quantidade de novas informações produzidas é de tal ordem, que nenhum indivíduo pode alimentar a esperança de estar ao corrente delas, mesmo que seja de uma ínfima parcela. E o problema que temos de enfrentar é o de possibilitar às pessoas que precisam de informações a sua obtenção com o mínimo de gastos (de tempo e de dinheiro) e sem que sejam assoberbadas por grandes quantidades de material irrelevante.

Assim para atingir esse objetivo os processos de tratamento temático que serão realizados pela biblioteca ou demais centros de informação ou em níveis mais simples pelos próprios pesquisadores ao terem como foco de suas pesquisas a taxonomia ou mesmo a organização da informação onde, vale-se de operações que não se resumem a técnicas ou procedimentos e modelos definidos que possam vir a ser estabelecidos e aplicados como fórmulas padronizadas. No âmbito da pesquisa aqui apresentada, Ferro (1985, p. 115) afirma que "todos os filmes são objetos de análise" e por apresentarem natureza documental podem ser considerados fontes históricas.

Dessa forma ressalta-se que no processo de representação temática da informação dois passos principais são utilizados, como aponta Novellino (1996, p.38):

1) análise de assunto de um documento e a colocação do resultado desta análise numa expressão linguística;

2) atribuição de conceitos ao documento analisado.

Embora se almeje uma sistematização desses processos que possa proporcionar a sua melhoria, ainda encontram-se sérias implicações, e entre as principais, estão as concernentes à análise e definição de assuntos, um dos pontos de maior divergência no tratamento temático.

Tal afirmativa é comprovada quando analisamos os próprios termos utilizados para designação das várias formas de homossexualidades manifestadas em tempos hodiernos, onde as 
siglas evoluem em uma tentativa de englobar toda uma gama de sujeitos que praticam modalidades alternativas de sexualidades. Sexualidades essas desviantes da biopolítica e principalmente da heteronormatividade vigente. Ressalta-se ainda que existe uma gama de variadas praticas homossexuais que estão englobadas pelas homossexualidades de onde emergem a classificação generalista estabelecida quanto a representação das homossexualidades no quadro panorâmico das produções analisadas, pois a mesma foi elaborada a partir do tipo de prática homossexual presente na produção cinematográfica, sendo elas organizadas da seguinte forma:

- Homossexualidades masculinas (HM): personagens masculinos que apresentam a homossexualidade como orientação ou pratica sexual, independentemente de sua função dentro da relação de natureza sexual;

- Homossexualidades femininas (HF): personagens femininos que apresentam a homossexualidade como orientação sexual ou pratica, independentemente de sua função dentro da relação de natureza sexual;

- Bissexualidade (B): personagens masculinos e/ou femininos que apresentam a bissexualidade como orientação sexual, independentemente de sua função dentro da relação de natureza sexual;

- Trans: personagens masculinos e/ou femininos que apresentam comportamento travesti ou transsexual, seja por ordem dos desejos ou mesmo por identificação;

- Transformismo ${ }^{13}$ : personagens masculinos e/ou femininos que se apresentam enquanto transformistas seja por criação do enredo fílmico, por função laborativa, pela ordem dos desejos ou mesmo por identificação.

\section{Resultados e análises}

Após cartografia necessária para a realização de tal pesquisa (etapa de reconstrução memorial) se pode compreender as proporções que o cinema nacional com temática homossexual ou mesmo com a presença de personagens homossexuais ocupam no cenário nacional.

Assim ao observar no Gráfico 1, o recorte cronológico compreendido entre os anos de 1980 a 2014, estabelecido pela pesquisa aqui representada, se pode compreender que a produção cinematográfica que apresenta em seu enredo personagens homossexuais tem uma relação desproporcional com relação a proporção de títulos entre as décadas de 1960 e 1970, causando

\footnotetext{
13 O transformismo entra como manifestação da homossexualidade pois representa uma forma de "borrar" as fronteiras entre os gêneros, compreendemos que as práticas das homossexualidades vão além do ato sexual ou o papel desempenhado no mesmo.
} 
certa ruptura com as décadas anteriores e gerando um novo campo para a produção e visibilidade de obras com tal natureza.

\section{Gráfico - Produção cinematográfica com personagens homossexuais (1920-2014) destacando o recorte cronológico (1980-2014)}

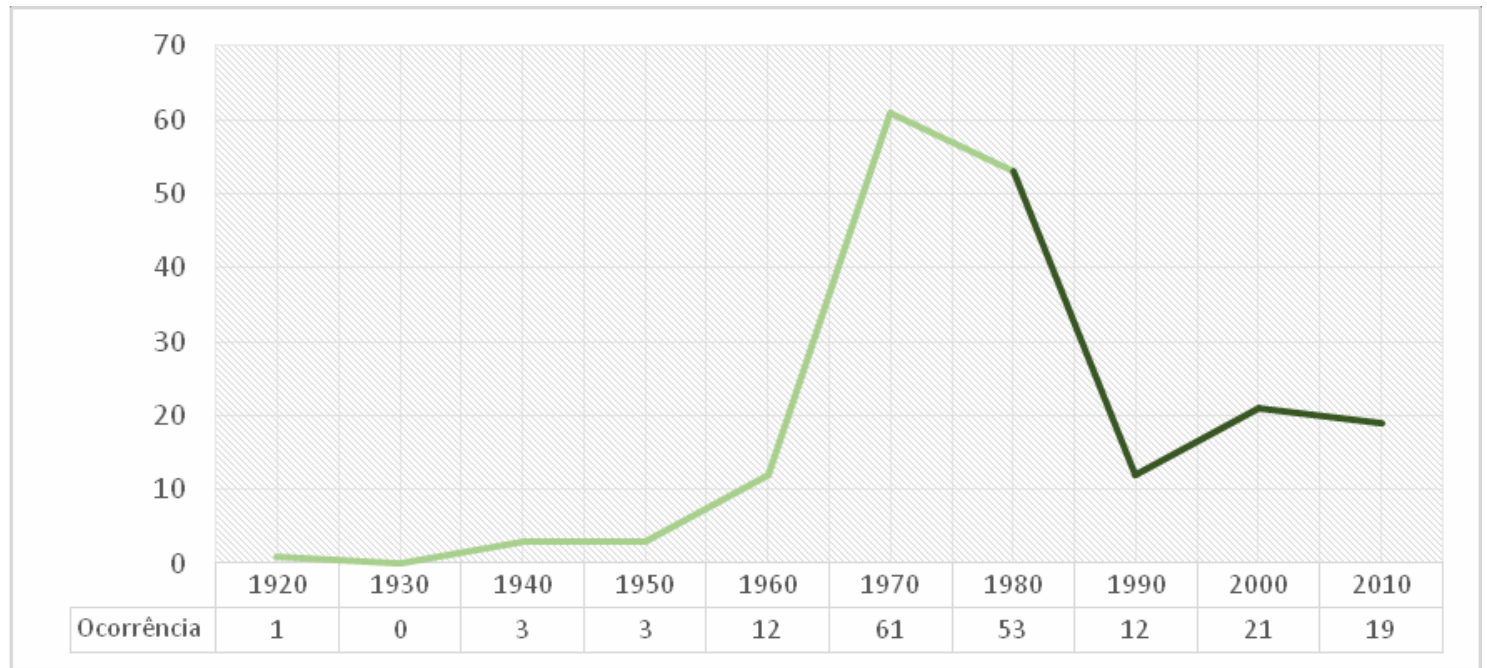

Fonte: Elaborado pelos autores

A produção de cinema na década de 1970, no Brasil, é muito intensa devido aos avanços alcançados nas diversas associações de cinema que se formam em diversos congressos e festivais. E, sobretudo pela atuação da Embrafilme, como órgão centralizador e de leis que protegiam a fatia do mercado de exibição obrigatória de cinema brasileiro. O que propiciava o aumento da produção e formação de distribuidoras particulares de cinema sem nenhum vínculo com a estatal Embrafilme.

Na década seguinte se pode observar uma continuidade na vasta produção de títulos e de abordagens do tema o que se confirma nas décadas seguintes, o que permite uma melhor distribuição dos 105 títulos analisados em seis gêneros: comédias, musicais, ficção, suspense, policial e dramáticos.

Diante do contexto que se desenhou durante a pesquisa se pode elaborar os Quadro 1, 2, 3 e 4 elencando os filmes em que existe a ocorrência de personagens homossexuais compreendida no recorte (1980-2014), ressalta-se que como primeira forma de organização de tais informações que emergem dos elementos fixos das produções cinematográficas distribuídos por década, e destacando título, ano de lançamento da obra, diretor, ator que interpreta o personagem 
homossexual na obra, o nome do próprio personagem e o tipo de homossexualidade apresentado no enredo fílmico.

Na década de 1980 ainda se prolifera em títulos com personagens homossexuais que se utilizam de forte apelo sexual, o que se coloca preponderantemente até a metade da década. Isto devido ao declínio total da produção cinematográfica brasileira estigmatizada pela derrocada da Embrafilme, que representou o corte jurídico das leis protecionistas ao mercado de exibição da produção cinematográfica feita no Brasil.

Os aspectos políticos começam a intervir de forma profunda na produção cinematográfica o que compromete a continuidade da produção fílmica da época e pode ser observada através do declínio no decorrer da década de 1980 e nas décadas seguintes. Mesmo sob a interferência do impacto de tal acontecimento foram registrados 53 títulos que apresentavam em seu enredo personagens homossexuais distribuídos nas seguintes categorias: 45 dramas, 1 musical, 5 comédias e 2 policiais. Tal distribuição evidencia uma ruptura com as décadas anteriores onde as comédias (pornochanchadas) predominavam nas produções que apresentavam em seu enredo personagens homossexuais. É importante ressaltar que em 31 obras a homossexualidade masculina foi representada em algum de seus aspectos, sendo a homossexualidade feminina

apresentada em 21 obras, a bissexualidade ocorre em 2 obras, os personagens trans são representados em 11 obras e o transformismo é evidenciado em 6 obras cinematográficas como se pode observar na Figura 1.

Figura 1- Filmes brasileiros com personagens homossexuais (1980-1989) 


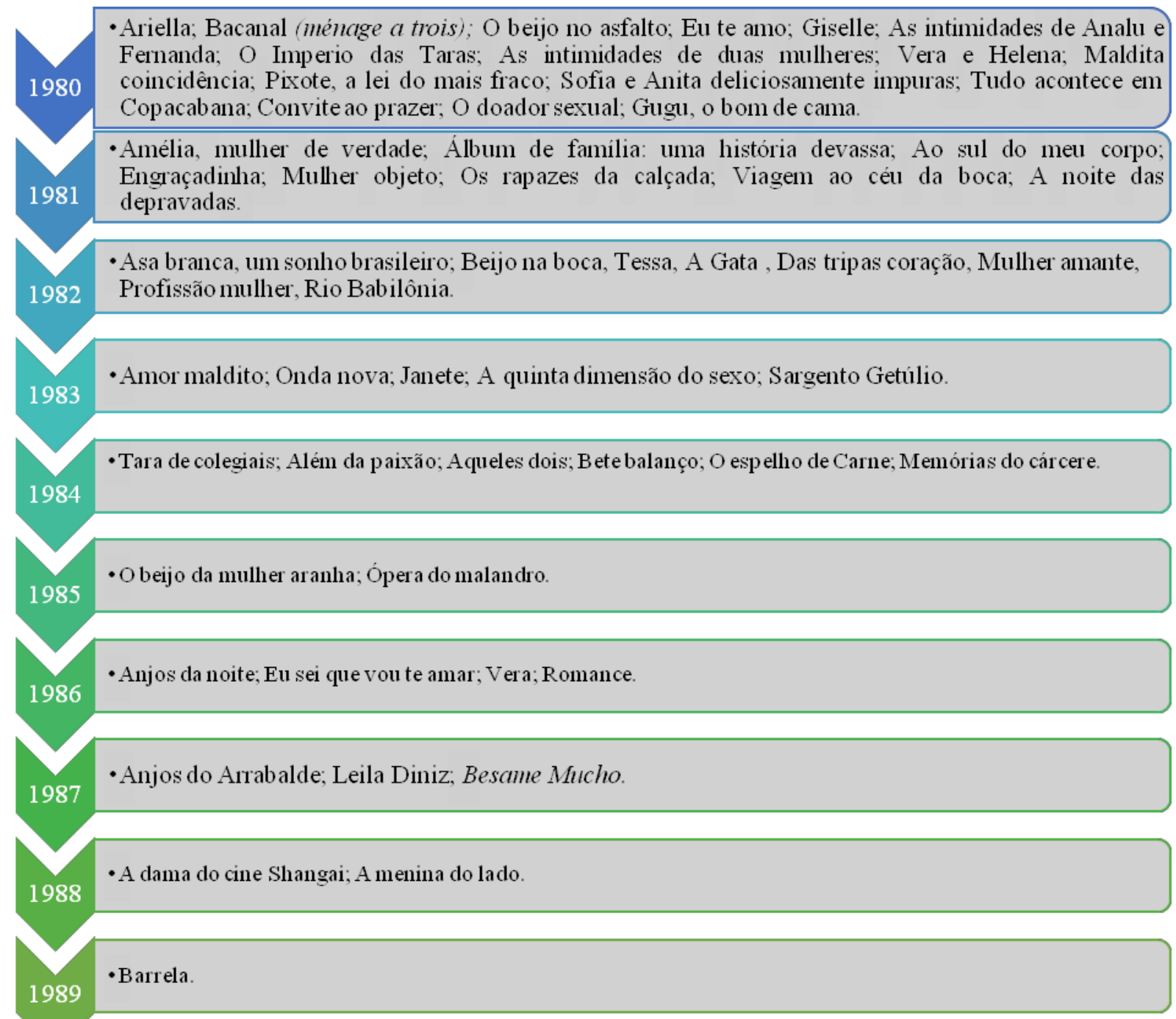

Fonte: Elaborado pelos autores, 2015.

Na década de 1990 e décadas seguintes se pode observar uma crescente retomada ${ }^{14}$ da temática que sofreu ecos da década anterior durante a sua primeira metade com relação a falta de investimentos. Ressalta-se um amadurecimento da abordagem iniciada na década de 1980 e todo um processo de humanização dos personagens que até este período eram distorcidos e inverossímeis, o que certificava a construção de uma estereótipo que pouco auxiliava nos debates acerca da temática e da representatividade social de tal personagens. Sob esses aspectos foram registrados 12 produções distribuídas da seguinte forma: 8 dramas, 2 comédias, 1 animação e 1 ficção. A distribuição das tipologias de representações das homossexualidades são distribuídas da seguinte forma: 7 obras evidenciam a homossexualidades masculina, 2 a homossexualidade feminina, 2os sujeitos trans e 1 o personagem bissexual é evidenciado. Percebe-se que o

\footnotetext{
${ }^{14} \mathrm{O}$ recuo na produção cinematográfica nacional pode ter sido reflexo da extinção da Embrafilme como órgão oficial de cinema no Brasil no final da década de 1980.
} 
transformismo tão presente em décadas anteriores não apresenta representação na década de 1990 o que evidencia um novo direcionamento nas produções cinematográficas nacionais, ver Figura 2.

Figura 2: Filmes brasileiros com personagens homossexuais nos anos de (1990-1999)

\begin{tabular}{|l|l|}
\hline 1990 & $\cdot$ Beijo $2348 / 72$ \\
\hline 1991 & - Matou a familia e foi ao cinema; O corpo. \\
\hline 1992 & Perfume de Gardênia. \\
\hline 1994 & - Rocky e Hudson. \\
\hline 1997 & - Navalha na carne; Bocage, o triunfo do amor; Amores. \\
\hline & - Até que a vida nos separe; O dia da caça. \\
\hline
\end{tabular}

Fonte: Elaborado pelos autores, 2015.

Na primeira década do séc. XXI foram encontrados 21 títulos alocados em 15 dramas e 6 comédias, distribuídos sob as seguintes tipologias: 13 títulos representam a homossexualidade masculina, 4 a homossexualidade feminina, 1 a bissexualidade é representada, 1 com personagem tranformista e em 7 são encontrados personagens trans. Nesse momento se pode observar que as homossexualidades femininas aparecem de forma tímida dentro do contexto fílmico evidenciando a ruptura com os estereótipos norteados pelas fantasias sexuais masculinas, muito recorrentes em décadas anteriores principalmente na de 1980 e nas ditas pornochanchadas. O personagem trans emerge nesse período dado o debate social que se intensifica em tal década sob o as demandas sociais pela despatologização das identidades trans, que emergem dos discursos dos movimentos sociais e adentram ao campo das representações sociais. Ressalta-se que os documentários como Dzi croquetes (2009) e as biografias, tais como Madame Satã (2002), Carandiru (2003), Cazuza O tempo não para (2004), permeiam os títulos desse período vivificando e dando um teor verossimilhante aos personagens homossexuais o que traz a cena discursos que apresentam teor político, humano e social próximos dos personagens homossexuais. 
Figura 3: Filmes brasileiros com personagens homossexuais nos anos de (2000-2009)

• Cronicamente Inviável

- A partilha; Amores possiveis; Lavoura arcaica; Netto perde sua alma.

-Viva sapato!; Dois perdidos numa noite suja; Madame Satã.

- Carandiru; Amarelo manga.

- Cazuza - O tempo não para.

-Irmã Vap - O retorno; Acredite, Um Espírito Baixou em Mim.

- Ópai, ó

- A guerra dos Rocha; Onde andará Dulce Veiga?

Fonte: Elaborado pelos autores, 2015.

Nos primeiros anos da segunda década do séc. XXI compreendido nos anos de (20102014) se pode observar as seguintes distribuição: 14 dramas e 5 comédias alocados em 15 obras com personagens homossexuais masculinos, 4 com homossexuais femininos, 2 com personagens trans, 1 em que ocorre personagem bissexual e 2 com personagem transformista.

Figura 4: Filmes brasileiros com personagens homossexuais nos anos de (2010-2014) 
- As melhores coisas do mundo; Como esquecer.

- A novela das 8; Elvis e Madona; Teus olhos meus.

2012

-Paraísos artificiais; Eu Te Amo Renato.

- Serra Pelada; Flores raras; Tatuagem; Minhamãe é uma peça; Somos tão jovens; Crô; O concurso; Do lado 2013 de fora.

2014

-Rio, eu te amo; Hoje eu quero voltar sozinho; O Casamento de Gorete; Praia do Futuro

Fonte: Elaborado pelos autores, 2015. 
Com relação ao contexto dos trinta e quatro anos analisados sob os aspectos políticos, sociais e culturais emergem nos discursos e composições dos personagens homossexuais uma imagem de sujeito alienado da realidade político-social, apresentando baixa escolaridade, manifestado em todo um linguajar característico do estereótipo criado em décadas anteriores e chancelado pela sociedade que condiciona o sujeito a uma representação simplificada e distante da realidade. Ressalta-se ainda o forte apelo sexual de tais personagens que ora são apresentados como profissionais do sexo ou temporariamente utilizados como recurso de ascensão social ou reparo financeiro momentâneo, sobretudo pelos jovens.

A relação do personagem homossexual e a classe social que o mesmo ocupa geralmente é desfavorável sendo o mesmo principalmente nas produções da década de 1980 e 1990 pobre como se pode observar em "Pixote, a Lei do Mais Fraco" (1980), "Vera" (1986) e "Navalha na carne" (1997), característica essa que começa a ser desconstruída na década seguinte com uma distribuição mais homogênea entre as classes sociais, como se pode observar em "A partilha" (2001), "Do começo ao fim"(2009) e "Novela das 8" (2011), onde os personagens homossexuais são apresentados em classes abastardas e em funções

diferenciadas das voltadas a prostituição.

Estigmas sociais emergem nas produções cinematográficas e certificam o estereótipo que se criou acerca das homossexualidades, a exemplo: Os homossexuais têm profissões variadas, mas na maioria apresenta um subemprego como lavadeiras, faxineiros, desocupados ou são apresentados como presidiários ou marginais perigosos como se pode observar em "Navalha na carne” (1997),“Giselle” (1980), “O Beijo da Mulher Aranha” (1985), "Madame Satã" (2002) entre outros e no caso das travestis/transformista todas são prostitutas ou fazem shows em boates como em: "Eu Te Amo" (1980), "Beijo na Boca" (1982), "Eu sei que vou te amar" (1986), “Anjos da Noite” (1986), “Rio Babilônia” (1982), “Opera do Malandro”(1985), "Madame Satã"(2002) entre outros, o que pode ser compreendido como uma condição de existência imposta a tais sujeitos como se aquele lugar fosse o único lugar onde podem existir como tal.

Em quase todo o universo analisado os homossexuais desempenham relações sexuais em troca de dinheiro seja por meio da prostituição propriamente dita como é o casa das travestis e dos michês ou através de mordomias, casa, apartamento, carro entre outros benefícios, como se pode observar em "Madame Satã" (2002), "Navalha na Carne" (1997), “Anjos da Noite" (1986), “Além da Paixão" (1984) entre outros. 


\section{Conclusões}

Do exposto, conclui-se que o retrato social dos personagens homossexuais feito pelo cinema brasileiro é em grande parte inverossímil. Pois, dos filmes analisados, poucos se preocuparam em dar um tratamento temático humanístico, onde o personagem não é marginal, alocado em espaço de tráfico de drogas ou prostituição, apresentando tendências ao crime e à alienação política.

Após o processo analítico quatro resultados podem ser observados nas produções cinematográficas brasileiras no período analisado. O primeiro resultado observado é que na produção cinematográfica nacional existe uma forte carga de estereótipos e outras características que contribuem para consolidação e a replicação dos preconceitos. Ressalto que conforme Bhabha (2005) "o estereótipo é uma pré-construção ou uma montagem 'ingênua' da diferença que autoriza a discriminação".

Como segundo resultado podemos apontar que a produção cinematográfica caracteriza os personagens com alguns elementos da comunidade homossexual de forma verossimilhante,

construindo assim um contra discurso que atua como ação política no combate aos preconceitos estabelecidos. Por outro lado, como terceiro resultado, pode-se afirmar que ainda ecoam produções que fazem uso de características de um modelo heteronormativo que contribui para a reduplicação dos preconceitos.

Emerge das análises como quarto resultado as produções que indicam uma representação dúbia que produz a dúvida sobre o tratamento dado ao personagem homossexual no enredo fílmico. Logo, se compreende que as qualidades atribuídas aos personagens homossexuais nos filmes brasileiros analisados, o retrato social do homossexual, de forma condensada, seria a de um sujeito politicamente alienado, existente em todas as classes sociais, com preponderância na classe média baixa, onde, geralmente, tem um subemprego, de comportamento agressivo e que usa, frequentemente, um gestual feminino exacerbado, o que se estende ao gosto pelo vestuário; e que, nos relacionamentos interpessoais, mostra tendência a solidão e é incapaz de uma relação monogâmica pois utilizase de vários parceiros, geralmente pagos, para ter companhia.

Assim, se pode observar que o modelo construído pelo cinema brasileiro é um modelo cruel e distante da realidade, que exalta pontos negativos, representando apenas as facetas contrárias a evolução do discurso em torno das homossexualidades no cenário contemporâneo. Mas, a visão que se depreende e que, especularmente, existe só. É importante ressaltar que existe um espaço crescente para esta temática e que as produções 
cinematográficas das últimas duas décadas tem revelado uma evolução acerca da contribuição da imagem gerada pelo cinema do personagem homossexual auferindo um espaço e adotando um discurso político social de transformação do personagem homossexual.

\section{Referências $^{15}$}

ALBUQUERQUE JÚNIOR, D. M. de. A invenção do Brasil e outras artes. 4.ed. São Paulo: Cortez, 2009.

BHABHA, H. K. O local da cultura. Belo Horizonte: UFMG, 2005.

BUTLER, J. Deshacer el género. Barcelona: Paidós, 2006.

CANEVACCI, M. Antropologia do Cinema. São Paulo: Brasiliense, 1990.

CHARTIER, Roger. A História cultural: entre práticas e representações. Lisboa: DIFEL, 1990.

FERRO, M. Y a-t-il une vision filmique de l'histoire. In: L'histoire sous surveillance. Paris: Calman-Lévy, 1985.

FOUCAULT, M. História da sexualidade: a vontade de saber. Rio de Janeiro: Graal, 1988.

FOUCAULT, Michel. Sobre a história da sexualidade. In: Microfísica do poder. Rio de Janeiro: Graal, 2000, p. 243 - 27.

FOUCAULT, M. Vigiar e punir: nascimento da prisão. Petrópolis: Vozes, 2009.

FOSKETT, A. C. Abordagem temática da informação. São Paulo: Polígono; Brasília: Ed. da UnB, 1973.

GONDAR, J.; DODEBEI, V. O que é memória social? Rio de Janeiro: Contra Capa Livraria/ Programa de Pós-Graduação em Memória Social da Universidade Federal do Estado do Rio de Janeiro, 2005.

GUEDES, E. G. F. O conceito aboutness na Organização e Representação do

Conhecimento. 2009. 90 f. Dissertação (Mestrado em Ciência da Informação)- Faculdade de Filosofia e Ciências, Universidade Estadual Paulista, Marília, 2009.

HALBWACHS, Maurice. Les cadres sociaux de la mémoire. Paris: Presses Universitaires de France, 1925.

HALBAWACHS, Maurice. A memória coletiva. São Paulo: Centauro, [1950] 2006.

KESSEL, Zilda. Memória e memória coletiva. São Paulo: Museu da Pessoa, Artigos, 2014. Disponível em:

<http://www.museudapessoa.net/public/editor/mem\%C3\%B3ria_e_mem\%C3\%B3ria_coletiv a.pdf $>$. Acesso em: 29 ago. 2016.

\footnotetext{
${ }^{15}$ Tendo em vista o extenso número de filmes analisados e seu uso como campo empírico, optou-se por omitir suas referências. Entretanto, todos estão mencionados por seus títulos no percurso metodológico.
} 
LEUTRAT, Jean-Luis. Uma relação de diversos andares: cinema e história. Imagens, Campinas, n. 5, p. 28-32, ago./dez. 1995.

MORENO, A. do N. A personagem homossexual no cinema brasileiro. Campinas: Eduff, 1995.

MORENO, A. do N. A personagem homossexual no cinema brasileiro. Niterói: Eduff, 2001.

NOVELLINO, M. S. F. Instrumentos e metodologias de representação da informação.

Informação \& Informação, v.1, n.2, p. 37-45, jul./dez., 1996.Disponível em:

$<$ http://www.uel.br/revistas/uel/index.php/informacao/article/view/1603>. Acesso em 10 set. 2016.

NORA, Pierre. Entre memória e história: a problemática dos lugares. Tradução: Yara Aun Khoury. Projeto História, São Paulo, v. 10, p. 7-28, 1993. Disponível em: $<$ http://revistas.pucsp.br/index.php/revph/article/viewFile/12101/8763>. Acesso em: 5 set. 2016.

OTLET, Paul. Documentos e documentação. Tradução livre. Responsável: Hagar Espanha Gomes. [introdução aos trabalhos do Congresso mundial da Documentação Universal, realizado em Paris, em 1937]. Disponível em: < http://www.conexaorio.com/biti/otlet/>. Acesso em: 03 ago. 2015.

PERET, Luiz Eduardo Neves. Do armário à tela global: a representação social da homossexualidade na telenovela brasileira. 2005, 246f. Dissertação (Mestrado em Comunicação)- Faculdade de Ciências Sociais, UERJ, Rio de Janeiro, 2001.

PINTO-MOLINA, Maria. Analisis documental: fundamentos y procedimientos. Madrid: Eudema. 1993.

POLLAK, M. Memória, esquecimento, silêncio. Estudos Históricos, Rio de Janeiro, v. 2, n. 3, p. 3-15, 1989.

ROSSINI, M. de S. Discursos sobre identidades culturais no cinema brasileiro dos anos 90. In: ENCONTRO DE NÚCLEOS DE PESQUISA DA INTERCOM, 4., Porto Alegre, 2004.

SPARGO, T. Foucault y la teoria queer. Barcelona: Gedisa, 2004.

WOODWARD, K. Identidade e diferença: uma introdução teórica e conceitual. In: SILVA, T. (Org.). Identidade e diferença: a perspectiva dos estudos culturais. Petrópolis: Vozes, 2000. 